\title{
Embryonic stem cell patents at European top court
}

\author{
André den Exter ${ }^{\star, 1}$ \\ European Journal of Human Genetics (2016) 24, 311; doi:10.1038/ejhg.2015.98; published online 1 July 2015
}

Embryonic stem cell research has long been controversial. Although it opens doors for new medical therapies for several diseases, opponents claim that it is wrong for ethical reasons. Many western countries are struggling with the dilemma between fostering biotechnological innovation in health care by means of patenting and respecting the core ethical and legal principles of human dignity and integrity. This clash between 'new' and 'old' values was ultimately resolved by the Court of Justice of the European Union in a highly contested ruling in 2011, the Brüstle case. ${ }^{1}$

Established in the first place to protect the European internal market - thus economic interests - this ruling, quite paradoxically, prohibited patents on stem cells from human embryos, as undermining human dignity. Although the alternative technology of induced pluripotent stem cells made the ruling appear already outdated, Brüstle made some researchers in Europe threaten to migrate to countries with a more liberal climate towards the patentability of embryonic stem cells. It seems, however, that the top lawyers in Luxembourg have been listening to medical scientists, as they did consider allowing certain methods of producing embryonic stem cell lines.

In its latest ruling, International Stem Cell Corporation v Comptroller General of Patents, ${ }^{2}$ the Court partially lifted its former ban on the patentability of the so-called parthenogenetic stem cell technique. In this technique, unfertilised eggs are chemically and electrically activated to initiate the process of cell division and development (parthenogenesis). Although the Court confirmed the general principle that the human body, or a human embryo at any stage, in its development cannot be patented, simultaneously it ruled that processes which lead to organisms incapable of developing into human beings, should be patentable under EU law. Among patent lawyers, this is considered a major breakthrough in which the Court seems to recognise that the Brüstle approach, by banning all property rights on embryonic stem cell techniques, is blocking innovation; therefore, it qualified as a legal error.

In line with the recommendation of the Court's adviser, Advocate General Cruz Villalón, the Court concluded that 'unfertilised human ovum whose division and further development to a certain stage have been stimulated by parthenogenesis, does not constitute a 'human embryo' under European Union law'. It was considered that such an ovum contains only pluripotent, and not totipotent, cells, and is thus incapable of development into a complete human being. These so-called 'parthenotes' do not inherently have the capacity of further development, which makes them open for patenting, thus commercialization. By contrast, this does not hold for a parthenote subjected to genetic manipulation. A human ovum that has this inherent capacity must be treated as a 'human embryo', and is thus unpatentable.

It seems that the Court with the capability test 'of commencing the process of development of a human being', has struck a balance between biotech research encouraged by patent law and, on the other hand, safeguarding human dignity and integrity. At the European level, there is no justification for a centralised exclusion from patentability when there is no capability of developing into a human being. However, the European court leaves it open to the national courts to decide whether or not human parthenotes have the inherent capability of developing into a human being. A negative answer, that is, no inherent capability, will be welcomed by the biotech industry to invest in parthenote-derived embryonic stem cell techniques and developing cell-based therapy for clinical applications (eg, regenerative medicine) ${ }^{3,4}$ Nevertheless, it remains to be seen whether the 'inherent capability test' is future proof; in other words, does the caveat on genetic manipulation go far enough? Moreover, we may ask: What's in it for patients? Will they benefit from these new medical technologies? It may seem obvious, but it is important to remember that patented innovations may harm patients' access to essential medicines and medical devices.

\section{CONFLICT OF INTEREST}

The author declares no conflict of interest.

\footnotetext{
1 CJEU Brüstle Oliver v Greenpeace case, C-34/10. 2011. Available at http://curia.europa.eu. (accessed 19 February 2015).

2 CJEU International Stem Cell Corporation v Comptroller General of Patents, C-364/13. 2014. Available at http://curia.europa.eu. (accessed 19 february 2015).

3 Yabut O, Bernstein HS: Human embryonic stem cells in regenerative medicine; in Bernstein HS (ed) Tissue Engineering in Regenerative Medicine, Stem Cell Biology and Regenerative Medicine. Humana Press: New York, NY, 2011; pp 17-38.

4 Yabut O, Bernstein HS: The promise of human embryonic stem cells in aging-associated diseases. Aging (Albany NY) 2011; 5: 494-508.
}

(i) (2) $\Theta$ This work is licensed under a Creative Commons Attribution-NonCommercial-NoDerivs 4.0 International License. The images or other third party material in this article are included in the article's Creative Commons license, unless indicated otherwise in the credit line; if the material is not included under the Creative Commons license, users will need to obtain permission from the license holder to reproduce the material. To view a copy of this license, visit http://creativecommons.org/licenses/by-nc-nd/4.0/

\footnotetext{
1Jean Monnet Chair EU Health Law, Erasmus University, Rotterdam, The Netherlands

${ }^{*}$ Correspondence: Dr A den Exter, Institute Health Policy and Management, Erasmus University, B Oudlaan 50, Room M5-39, 3000 DR Rotterdam, The Netherlands. Tel: +31 10408 1867; Fax: +31 10408 9092; E-mail: denexter@bmg.eur.nl

Received 21 January 2015; revised 5 April 2015; accepted 17 April 2015; published online 1 July 2015
} 